\title{
Resolving taxonomic problems through cuticular analysis in Early Cretaceous bennettitalean leaves from Patagonia
}

\author{
Martín A. Carrizo*, Maiten A. Lafuente Diaz, Georgina M. Del Fueyo \\ Museo Argentino de Ciencias Naturales "Bernardino Rivadavia", CONICET, Av. Ángel Gallardo 470, CP 1405, Buenos Aires, Argentina
}

\section{A R T I C L E I N F O}

\section{Article history:}

Received 30 October 2018

Received in revised form

7 January 2019

Accepted in revised form 13 January 2019

Available online 17 January 2019

\section{Keywords:}

Bennettitales

Ptilophyllum

Foliar cuticle

Springhill formation

Lower Cretaceous

Patagonia

\begin{abstract}
A B S T R A C T
The genus Ptilophyllum Morris is one of the most common bennettitalean leaf genera found in the Cretaceous megafloras from Western Gondwana, particularly Patagonia and Antarctica. Among several specimens, the similarity in the morphology of their leaves make them hard to distinguish from each other, which usually leads to misinterpretations. Therefore, the study of the epidermal features in this taxon is essential, especially because the occurrence of papillae, its size, forms, and distributions are relevant for the differentiation of species. Based on these considerations, the erection of a new Ptilophyllum species here indicated that the papillae are a key character to resolve taxonomic conflict between some of the Cretaceous taxa from Western Gondwana. Ptilophyllum eminelidarum sp. nov. Carrizo, Lafuente Diaz et Del Fueyo, was recovered from the Springhill Formation at the Río Correntoso and Estancia El Salitral localities, Santa Cruz province, Argentina. Epidermal foliar features are fully described with the aid of light and electron (SEM and TEM) microscopy. This new bennettitalean species is characterized by pinnate leaves with an epidermis bearing two distinct, uniformly distributed, papillae morphologies: the compound papillae are situated on the vein cells, and the small simple papillae are located between veins. The cuticular membrane ultrastructure consists of three layers corresponding to the cuticle proper (A2) with fibrillar aspect and the cuticular layers B1 and B2 with homogeneousgranular and fibrillar-granular aspect, respectively. This combination of features are unique to this species, differentiating it from other coetanean species of the genus from Western Gondwana. This finding complements and reinforces previous knowledge regarding the megaflora of the Springhill Formation and underscores the important role of the Bennettitales within the plant associations during the Cretaceous of Patagonia.
\end{abstract}

() 2019 Elsevier Ltd. All rights reserved.

\section{Introduction}

The cuticle is an inert amorphous non-cellular layer that is deposited on the outside of the epidermal cells of the plants. Due to their high resistance to decay, the cuticles often survive fossilization and diagenesis, becoming commonly preserved in the fossil record and representing a valuable source of paleobotanical information (Mösle et al., 1997; Pott et al., 2007; Taylor et al., 2009). Since the first mention of cuticle extraction made by Brongniart (1834), the role of the cuticles has become widely recognized not only in systematic and taxonomical studies, but also as part of palaeobiological and palaeoecological considerations (Nathorst,

\footnotetext{
* Corresponding author.

E-mail addresses: blackdisk@gmail.com (M.A. Carrizo), maitenlafuentediaz@ gmail.com (M.A. Lafuente Diaz), georgidf@yahoo.com.ar (G.M. Del Fueyo).
}

1908; Thomas, 1915; Florin, 1958; Harris, 1964; Oldham, 1976; Archangelsky et al., 1986; Archangelsky and Taylor, 1986; Cleal and Zodrow, 1989; Kerp, 1990; Kerp and Barthel, 1993; Carrizo et al., 2014; Guignard et al., 2016).

Cuticular studies have proved to be especially important in groups such as the Bennettitales. These Mesozoic plants were widely distributed on both hemispheres during the Mesozoic (Cúneo et al., 2010). Their leaves are very similar to that of the Cycadales, except for the presence in the Bennettitales of syndetocheilic stomata (in which it is presumed that both subsidiary and occlusive cells are derived from a single mother cell); the dorsal thickness of the occlusive cells, and the sinuosity of the anticlinal walls of the ordinary cells of most species (Harris, 1969; Archangelsky and Baldoni, 1972; Sincock and Watson, 1988; Taylor et al., 2009). Most of the Bennettitales also have very similar leaves, and the assignment of each specimen depends of characters such as the basal angle of insertion of the leaflets and 
their venation, which are sometimes difficult to discriminate due to different interpretation of the foliar characters or to preservation. Therefore, their leaves are often distinguishable only by epidermal features (Archangelsky, 1970; Watson and Sincock, 1992; Taylor et al., 2009).

The genus Ptilophyllum Morris is one of the most common bennettitalean leaves found in the Lower Cretaceous Springhill Formation in the province of Santa Cruz, Argentina. The pinnateleaves of Ptilophyllum are characterized by leaflets attached to the upper surface of the rachis with an asymmetrical base composed of a decurrent lower margin and a constricted upper margin, and with parallel veins that sometimes forks near the apex of the leaflets (Bose and Kasat, 1970; Sukh-Dev and Zeba-Bano, 1977; Taylor et al., 2009). In this contribution, the taxonomy of some problematic Ptilophyllum species from the Cretaceous of Patagonia and Antarctica is discussed. Furthermore, the foliar cuticle of a new bennettitalean species, Ptilophyllum eminelidarum sp. nov. Carrizo, Lafuente Diaz et Del Fueyo, recovered from the Lower Cretaceous Springhill Formation at the Río Correntoso and Estancia El Salitral localities in the Santa Cruz province, Argentina, is fully described with the aid of light and electron (SEM and TEM) microscopy. Finally, this new taxon is compared and clearly differentiated from other coetanean species of the genus from Western Gondwana.

\section{Geological and palaeobotanical background}

The Springhill Formation (Thomas, 1949) occurs in the NNW sector of the Austral Basin, covering the south of Argentina and Chile. It has a significant areal distribution but is partially to completely absent in certain localities. The large distribution and the transgressive characteristic of its deposits are also the cause of its heterochrony being late lower Hauterivian/lower Barremian at the proximities of the Estancia El Salitral locality and Valanginian/ Hauterivian and Berriasian?/Valanginian-lower Hauterivian at the subsurface of Chile, Tierra del Fuego province and the Continental Platform of Argentina (Riccardi, 1976; Cortiñas and Arbe, 1981; Ottone and Aguirre-Urreta, 2000; Giacosa and Franchi, 2001; Archangelsky and Archangelsky, 2004; Spalletti et al., 2009).

The most fertile outcrops of this formation occur at the proximities of the Estancia El Salitral and North of the Ghío Lake, in the Santa Cruz province of Argentina (Fig. 1), where numerous fossils were collected and studied (Carrizo et al., 2014; Carrizo and Del Fueyo, 2015). Among the macroflora recovered from the Springhill Formation, more than $45 \%$ of the diversity belongs to the Bennettitales, which includes several bracts of Cycadolepis Saporta, and leaves of Otozamites Braun and Ptilophyllum Morris (Carrizo and Del Fueyo, 2015).

The genus Ptilophyllum is present in the Springhill Formation with $P$. ghiense Baldoni from the Río Correntoso locality; $P$. valvatum Villar de Seoane and $P$. angustus Baldoni et Taylor, from the Estancia El Salitral locality; and P. antarcticum Archangelsky et Baldoni from core samples of Argentina and Chile. Ptilophyllum antarcticum is also recurrent at Piedra Clavada Formation (Albian) and at the Anfiteatro de Ticó Formation (Aptian) along with $P$. longipinnatum Menéndez and $P$. hislopii (Oldham) Seward (Menéndez, 1966; Archangelsky and Baldoni, 1972; Archangelsky, 1976; Baldoni, 1977, 1979; Baldoni and Taylor, 1983; Villar de Seoane, 1995, 2001, 2003).

\section{Materials and methods}

The fossils studied and described here include compressions of pinnate leaves of the bennettitalean Ptilophyllum Morris, with wellpreserved cuticle. The materials were extracted from pelitic levels of the Springhill Formation that outcrops at the Río Correntoso and Estancia El Salitral localities, Santa Cruz province, Argentina (Fig. 1).

For the extraction of the cuticles the leaves were gently removed from the sediment using entomological needles and soft hair brushes, and treated with $40 \%$ nitric acid followed by $5 \%$ ammonium hydroxide and cleared with sodium hypochlorite. Then, $5 \mathrm{~s}$ of ultrasound was applied to fully remove all of the carbonized mesophyll remnants. In some cases the leaves were macerated in hydrochloric acid (20\%) followed by hydrofluoric acid (70\%) to remove the recalcitrant carbonized mesophyll. For better observation of epidermal features with light microscopy (LM), the cuticles were stained with safranin and mounted in glycerin jelly. For scanning electron microscopy (SEM) observation, the cleaned cuticles were mounted on exposed film, glued to stubs and coated with gold-palladium. For transmission electron microscopy (TEM), selected fragments of leaf cuticles were prepared following the technique outlined in Del Fueyo and Archangelsky (2005). Each of the morphological and epidermal features were measured using at least an $\mathrm{n}>20$ sample.

The terminology for the cuticular membrane is that implemented by Archangelsky et al. (1986) and Guignard et al. (2016), in which the cuticular membrane (CM) includes the cuticular proper $(\mathrm{CP}=\mathrm{A} 1+\mathrm{A} 2)$ and the cuticular layer $(\mathrm{CL}=\mathrm{B} 1+\mathrm{B} 2)$.

The specimens of Pilophyllum longipinnatum and $P$. antarcticum used for comparison are located in the Paleobotanical Collection of the Facultad de Ciencias Naturales y Museo of the University of La Plata under the acronym LPPB.

LM observations were made with a Leica DM 2500 microscope and the micrographs taken with a Leica DFC 280 and a Leica ICC50 camera. SEM observations were made under a Philips XL30 TMP SEM at $15.1 \mathrm{kV}$ equipment at the Museo Argentino de Ciencias Naturales "Bernardino Rivadavia". Ultrathin sections were prepared with a Sorval automatic ultramicrotome, observed and photographed with a Jeol JEM 100C camera at the Electronic Microscopy Laboratory of CICV-INTA Castelar. All the materials of Ptilophyllum eminelidarum sp. nov. are deposited in the Paleobotany Collection of the Regional Museum Padre MJ Molina, Río Gallegos, Santa Cruz Province, under the acronym MPM-PB.

\section{Systematic palaeobotany}

Division CYCADOPHYTA Taylor, Taylor \& Krings (2009) Order BENNETTITALES Harris (1969)

Genus Ptilophyllum Morris, 1840

Type species: Ptilophyllum acutifolium Morris, 1840

Ptilophyllum eminelidarum sp. nov. Figs. 2-6

Derivation of the name. It is a combination of the surnames Emi (short form for Emilio) and Nélida Cvjetanovic, owners of the Estancia Río Correntoso, who allowed us to work on their properties and made our stay in the field more comfortable.

Synonymy. 2015 Ptilophyllum sp.1., Carrizo and Del Fueyo, p. 100, 106, Fig. 6 (1-2).

Holotype. MPM-PB 15348.

Paratypes. MPM-PB 15347, 15349.

Locality and stratigraphy horizon. Río Correntoso and Estancia El Salitral, Santa Cruz Province, Argentina. Springhill Formation, lower Hauterivian-lower Barremian.

Diagnosis. Pinnate leaves with leaflets attached to the upper surface of the rachis; alternate to sub-opposite arranged; mostly linear with the distal portion slightly falcate; apex acute; upper margin entire and lower margin decurrent. Leaves hypostomatic. Adaxial epidermis smooth with sinuous anticlinal walls; periclinal walls with microgranular structure. Abaxial epidermis with poorly 


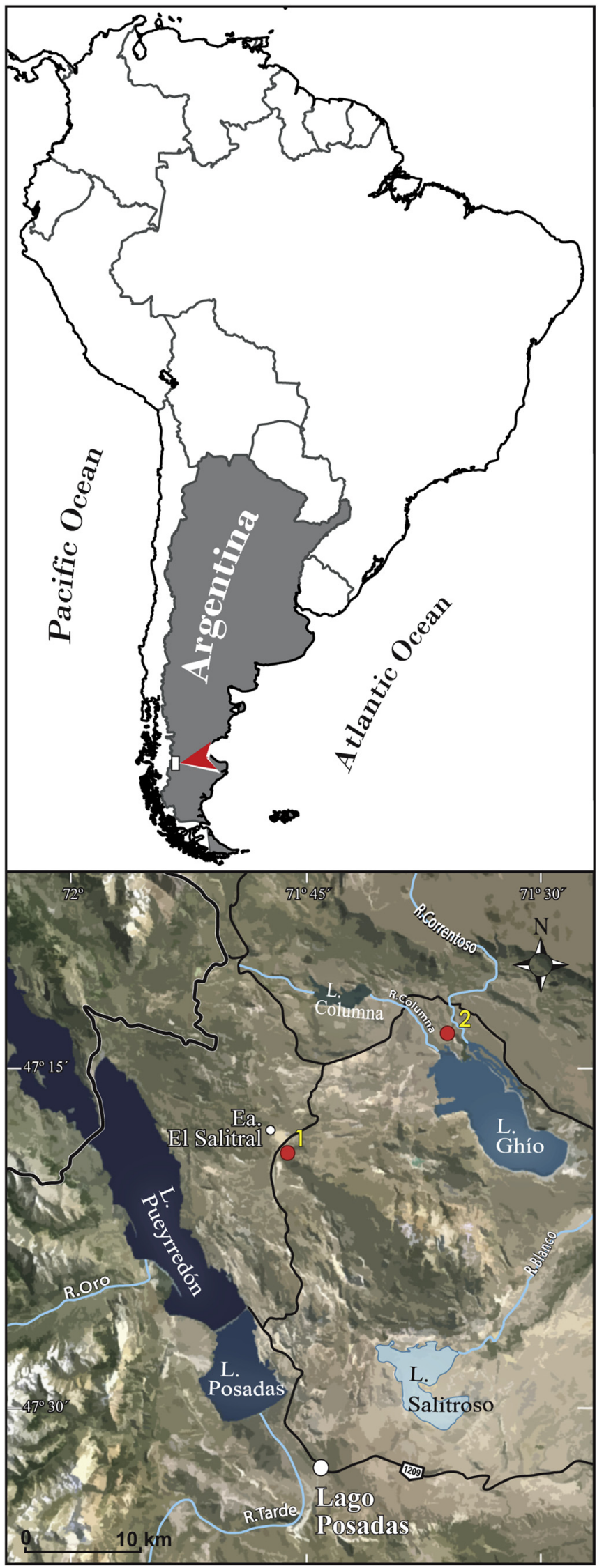

$0^{\mathbb{T}}$ Ea. El Salitral

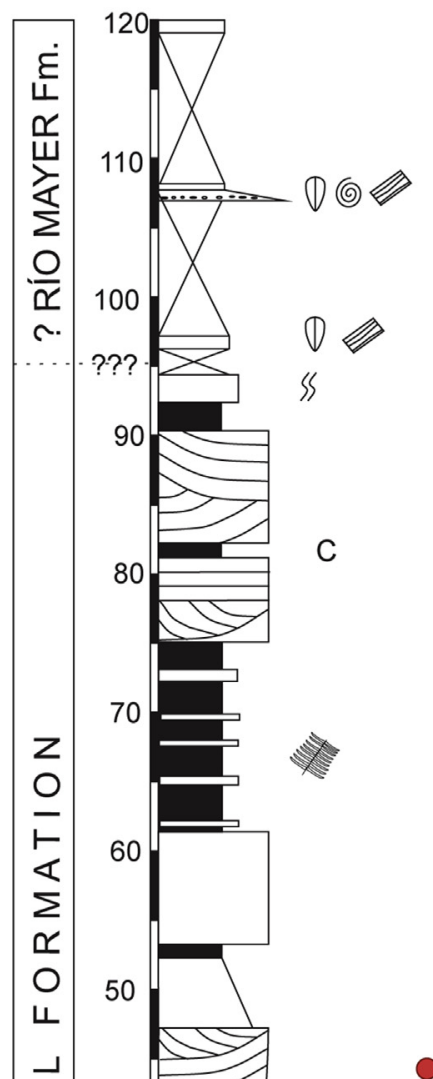

$0^{2}$ Río Correntoso

C Charcoal

Fossil leaves

Trunks

SS Bioturbation

(D) Shells

(a) Ammonites
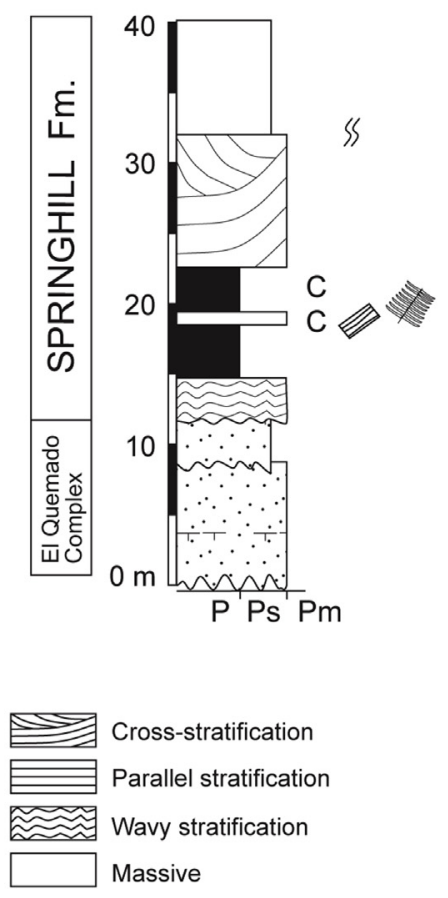

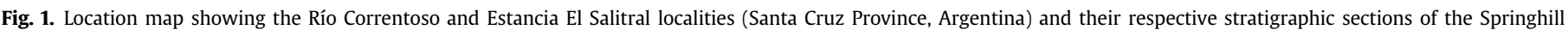
Formation. 

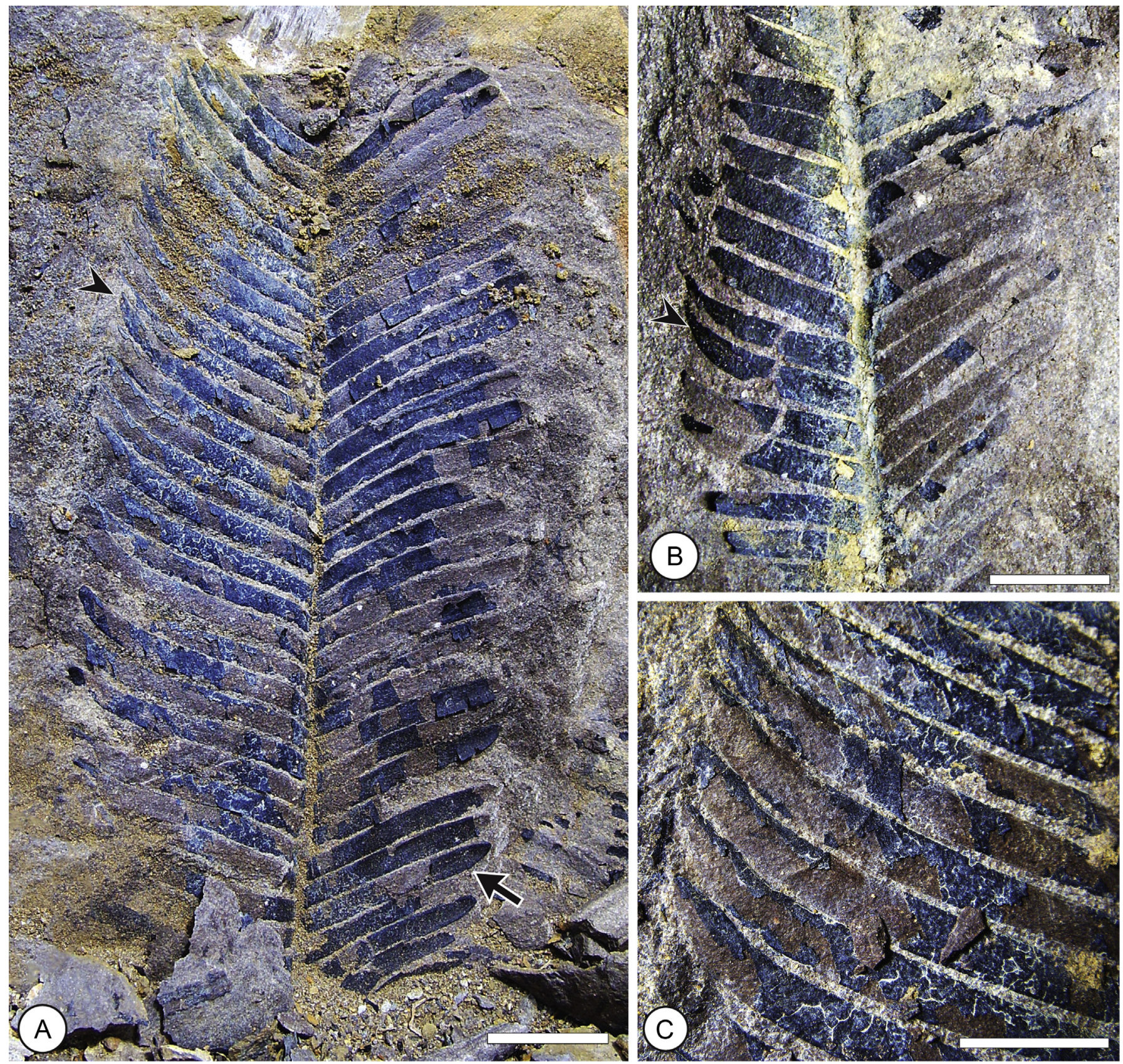

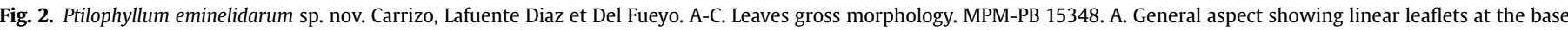
(arrow) and distally falcate leaflets at the apex (arrowhead). Scale bar: $2 \mathrm{~cm}$; B-C. Details of the leaflets, arrow head points the distally falcate leaflets. Scale bars $1 \mathrm{~cm}$.

marked anticlinal walls. Papillae uniformly distributed with two distinct morphologies. Those situated on the vein cells exclusively compound, those located on the ordinary cells among the stomata, mostly simple. Compound papillae with 5-10 irregular segments. Stomata in two or three rows, mostly aligned, perpendicularly oriented to the venation. Paracytic. Subsidiary cells may present a small simple papilla overarching the stomatal aperture. Guard cells sunken, with dorsal thickening. Ultrastructurally, the cuticular membrane has an outer A2 fibrillar layer; a homogeneous-granular B1 middle layer; and an inner B2 layer with fibrillar-granular aspect.

Description. The specimens consist of compressions of pinnate leaves up to $14.5 \mathrm{~cm}$ long and $6.9 \mathrm{~cm}$ wide with well-preserved cuticle (Fig. 2A-C). The leaflets are attached to the upper surface of the rachis, they are alternate to sub-opposite arranged, with spaces of $1 \mathrm{~mm}$ each, and in angles that vary from $45^{\circ}-80^{\circ}$ in the proximal part of the leaf, decreasing distally. The largest leaflets are $4 \mathrm{~cm}$ long and $0.44 \mathrm{~cm}$ wide, reaching $2.8 \mathrm{~cm}$ long and $0.25 \mathrm{~cm}$ wide at the apex of the leaf. They are mostly linear (Fig. 2A) with the distal portion slightly falcate; the apex is acute (Fig. 2A-C); the upper margin entire and the lower margin decurrent. The venation is parallel with $9-18$ veins per leaflet.

The leaves are hypostomatic. The adaxial epidermis is smooth (Figs. 3A and 4A) and consists of quadrangular to polygonal ordinary cells of varying sizes, with an average of $45.55 \mu \mathrm{m}$ long and $37.55 \mu \mathrm{m}$ wide (Figs. $3 \mathrm{~A}-\mathrm{B}$ and $5 \mathrm{~A}-\mathrm{B}$ ). The vein areas are poorly marked by cells with a more rectangular-elongated shape $(56.2 \mu \mathrm{m}$ 


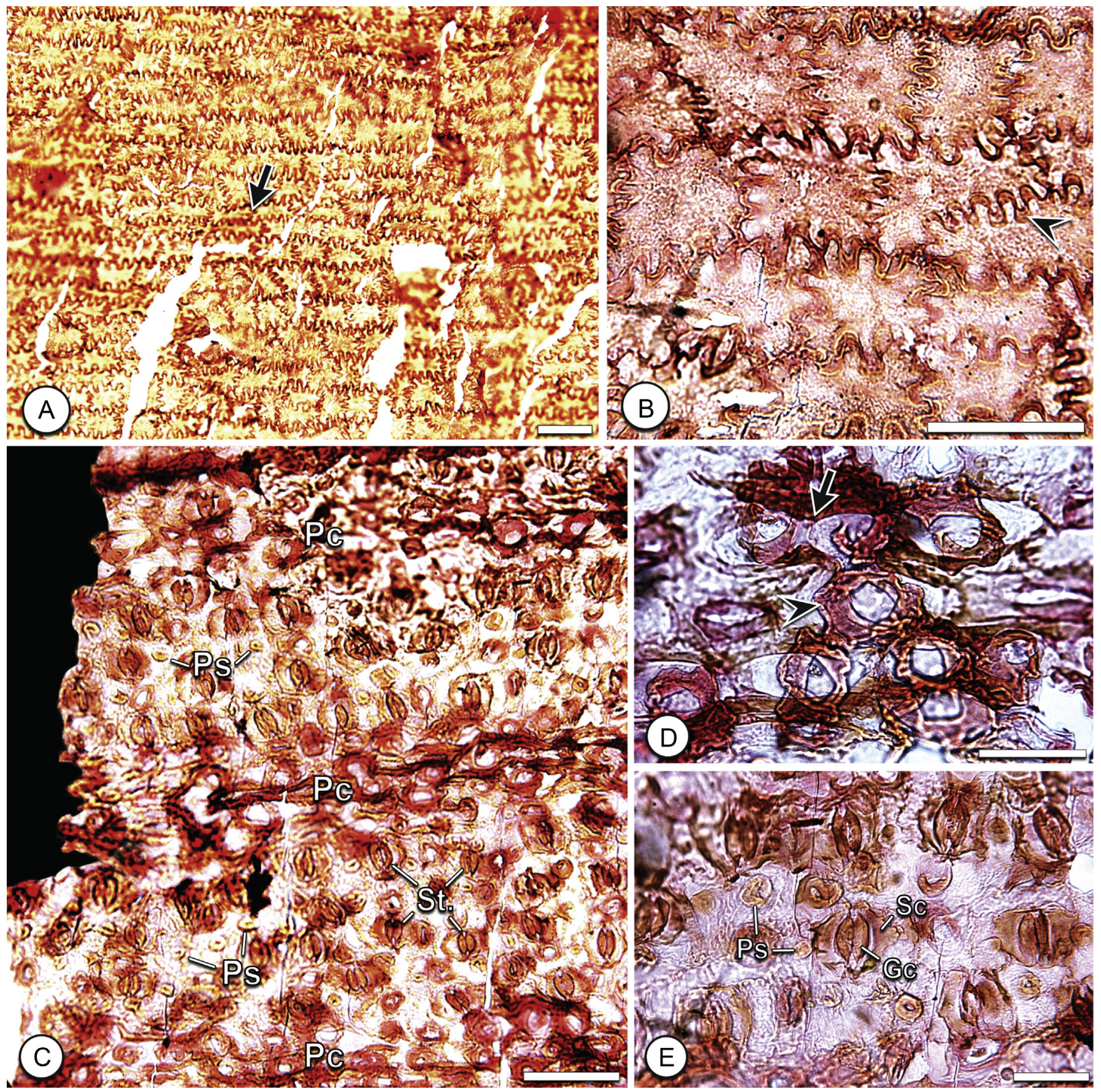

Fig. 3. Ptilophyllum eminelidarum sp. nov. Carrizo, Lafuente Diaz et Del Fueyo. A-E. Detail of epidermal cells and stomata with LM. Gc: Guard cell; Pc: Papilla compound; Ps: Papilla simple; Sc: Subsidiary cell; St.: Stoma. MPM-PB 15348. A-B. Adaxial epidermis. Scale bars $50 \mu \mathrm{m}$; A. Ordinary cells, arrow shows elongate vein cells; B. Detail of sinuous anticlinal walls (arrowhead); C. General aspect of abaxial epidermis. Note the compound papillae distributed exclusively on veins and simple papillae among the stomata. Scale bar $100 \mu \mathrm{m}$; D-E. Detail of the papillae. Scale bars $40 \mu \mathrm{m}$; D. Compound papillae (arrowhead) and fused compound papillae (arrow); E. Simple papillae and stomata.

long and $30.4 \mu \mathrm{m}$ wide) (Fig. 3A). The anticlinal walls of ordinary cells are markedly sinuous, with sinuosity of $7.6 \mu \mathrm{m}$ wide and $9.2 \mu \mathrm{m}$ deep, and a separation among crests of $\sim 4 \mu \mathrm{m}$. The periclinal wall presents a microgranular structure (Fig. 5B).

The abaxial epidermis has numerous papillae uniformly distributed with two distinct morphologies: those papillae situated on the vein cells are exclusively compound, while those located on the ordinary cells among the stomata, between veins, are simple (Figs. 3C and 4B-C). Both types of papillae are absent near the margin of the leaflets (Fig. 4E). The compound papillae are
29.1-51.95 $\mu \mathrm{m}$ wide and are conformed by an oval-rectangular base cell $34-61.35 \mu \mathrm{m}$ long and $22.03 \mu \mathrm{m}$ wide and each papilla shows 5 to 10 irregular lobulated segments, which in some cases are fused with other segments of neighbor papillae (Figs. 3D and 4B,D). The simple papillae are mostly dome-shaped, $12-17 \mu \mathrm{m}$ wide and their base-cells are quadrangular-isodiametric with a length and width of $31.20-34.40 \mu \mathrm{m}$, respectively (Figs. 3E and 4C). The anticlinal walls of the cells are poorly marked (Fig. 5C-D).

The stomata are distributed between veins in 2 or 3 rows of 125-212 $\mu \mathrm{m}$ wide. They are mostly aligned, perpendicularly 

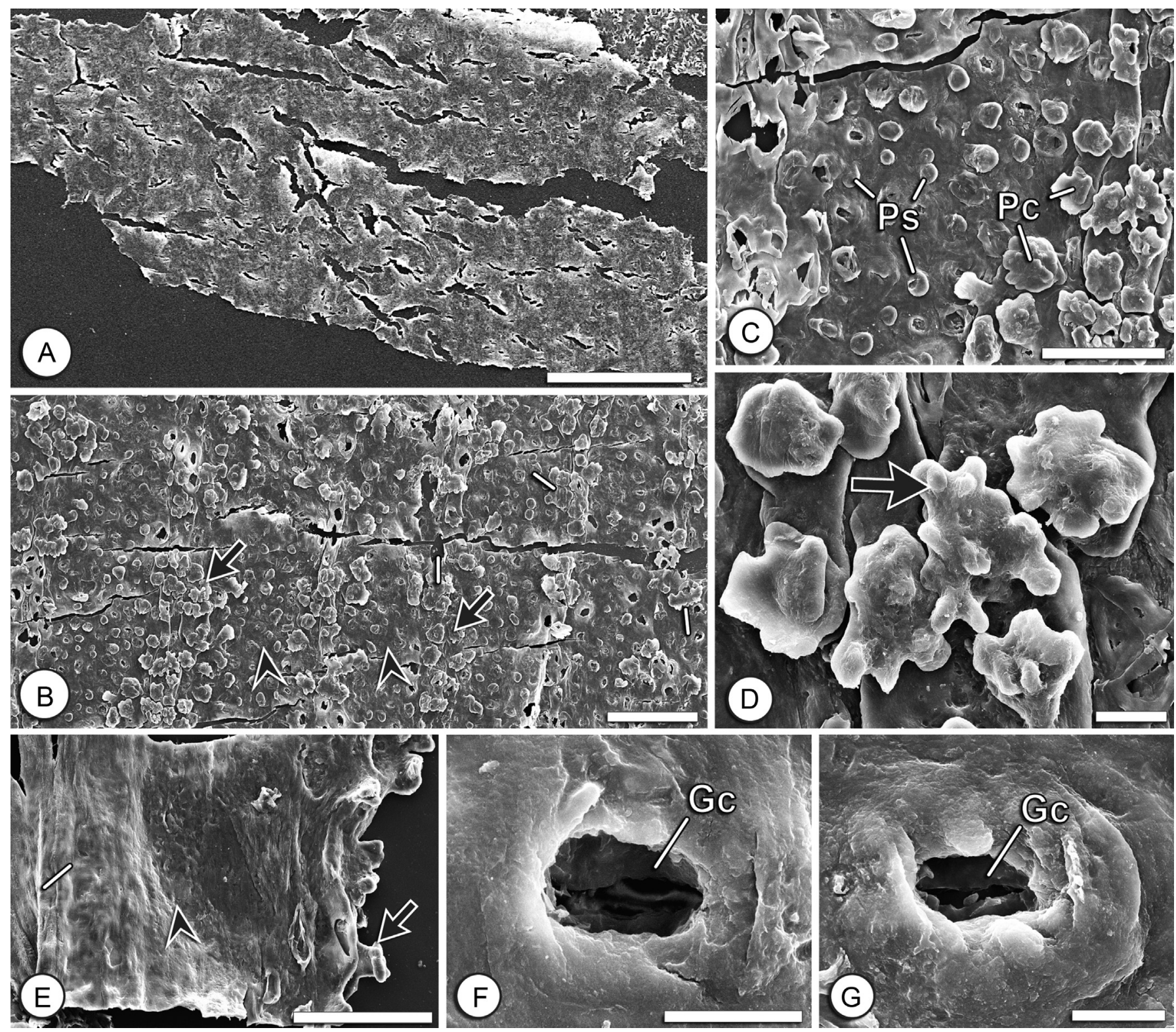

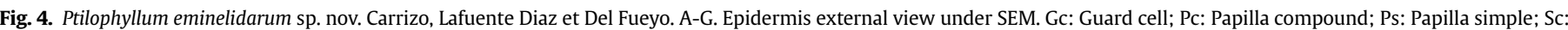

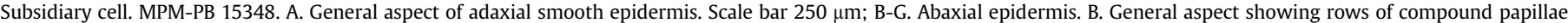



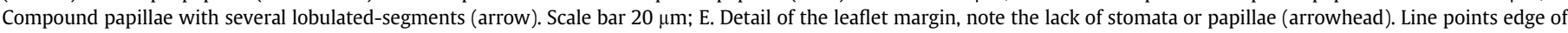
the lamina and arrow a compound papilla in lateral view. Scale bar $100 \mu \mathrm{m}$; F-G. Detail of sunken stomata. Scale bars $10 \mu \mathrm{m}$.

oriented to the venation and with a stomatal density of 105 per $\mathrm{mm}^{2}$ (Fig. 5C-F). The stomatal apparatus is paracytic, subrectangular, 28.5-46 $\mu \mathrm{m}$ wide and 39.5-61 $\mu \mathrm{m}$ long, with two isodiametric subsidiary cells $(28.5-46 \mu \mathrm{m}$ wide $\mathrm{x} 19.75-30.5 \mu \mathrm{m}$ long) (Fig. 5E-F). The guard cells are sunken (Fig. 4F-G), $28 \mu \mathrm{m}$ long and $10.5 \mu \mathrm{m}$ wide, with conspicuous dorsal thickening (Fig. 5E-F). The pit of $16.5 \mu \mathrm{m}$ long also appears thickened. In very exceptional cases the subsidiary cells show a poorly developed simple papilla.

The cuticular membrane of $1.6-4.9 \mu \mathrm{m}$ thick consists of three layers that correspond with the cuticle proper (A2) and the cuticular layers B1 and B2 (Fig. 6A-E). In ordinary epidermal cells the polylamellate layer A1, in the sense of Archangelsky et al. (1986) and Guignard et al. (2016), is not preserved. However, the outer A2 layer of $0.25-0.3 \mu \mathrm{m}$ thickness shows a fibrillar aspect (Fig. 6D). The B1 middle layer of 1-4 $\mu \mathrm{m}$ thickness is homogeneous-granular and is the less electron dense (Fig. 6C,E). The inner B2 layer has a fibrillar-granular aspect and is $\sim 0.25-0.3 \mu \mathrm{m}$ thick (Fig. $6 \mathrm{E}$ ). These same layers A2, B1, B2 are observed in the cuticular membrane of the papillae (Fig. 6A-B).

\section{Discussion}

\subsection{Ptilophyllum spp. from Western Gondwana and their problematic taxonomy}

A common issue when working with bennettitaleans foliage is the similarity in the morphology of their leaves, making them hard to distinguish from each other. This can lead to misinterpretations when a complete study of their cuticles is not carried out (Bose and Kasat, 1970; Mösle et al., 1997; Pott et al., 2007; Taylor et al., 2009; 

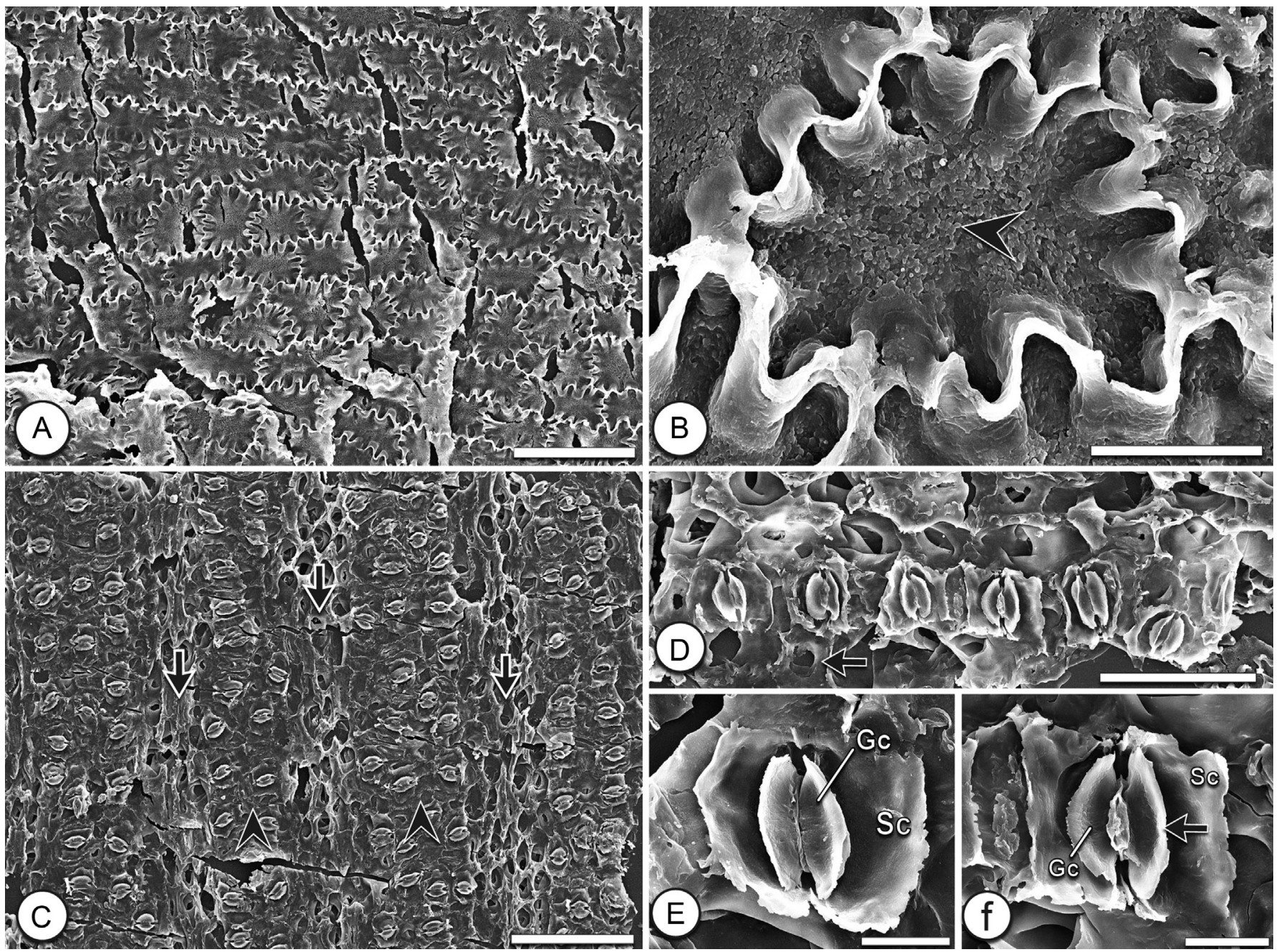

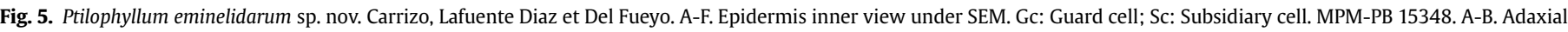

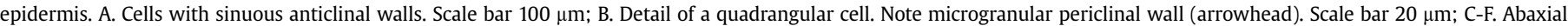

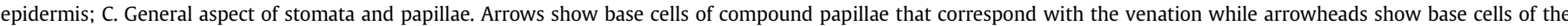

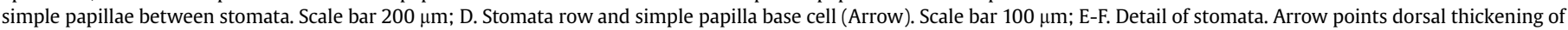
guard cells. Scale bar $20 \mu \mathrm{m}$.

Carrizo et al., 2014; Carrizo and Del Fueyo, 2015). As an example, the bennettitaleans Ptilophyllum antarcticum Archangelsky et Baldoni 1972 and P. longipinnatum Menéndez (1966) are two controversial species from Western Gondwana that were synonymized more than once with other genera and species according to different interpretations of their morphological features.

In 1972, Archangelsky and Baldoni made an extensive revision of all the bennettitalean fossils from the Baqueró Group and emended Ptilophyllum antarcticum (Halle) Seward assigning the materials of $P$. longipinnatum described by Menéndez (1966) as a synonym of the former species. Menéndez (1973) defended the validity of $P$. longipinnatum pointing out the differences in the size of the leaflets, but despite the morphological differences, Archangelsky (1976) referred it again to P. antarcticum. Years later, Gee (1989) revised the Jurassic Flora of Hope Bay (Antarctica) and included all the specimens of $P$. antarcticum and $P$. longipinnatum as synonyms of Zamites antarcticus Halle. Gee made that decision because the specimens observed by Halle (1913) that were included in $P$. antarcticum had the base of the leaflets not clearly defined but with a slightly constriction on both margins. This is a key morphological feature of the genus Zamites.
On the other hand, in the study of the Cretaceous flora from the Cerro Negro Formation (Antarctica), Cantrill (2000) suggested all the materials from the Baqueró group described by Archangelsky and Baldoni (1972), listed as Zamites antarcticus by Gee (1989), should be retained in Pitlophyllum because he observed that the basiscopic leaf margin in these materials is decurrent on the axis (a typical characteristic of Ptilophyllum). However, Cantrill (2000) included Archangelsky and Baldoni's specimens, with the exception of those of $P$. longipinnatum, as synonyms of a new species, Ptilophyllum menendezi, which he erected based only on the leaflet morphology and internal cuticular features, but without taking into account the epidermis's external characters, such as the presence of papillae. Because the type, form, and distribution of papillae are diagnostic characteristics of $P$. antarcticum, this taxon cannot be considered as a synonymous with $P$. menendezi from Cerro Negro. Therefore, $P$. antarcticum is here considered as the taxon originally emended by Archangelsky and Baldoni in 1972.

Based on the new cuticular feature observations (Fig. 7A-F) made herein on $P$. antarcticum and $P$. longipinnatum, we come to several conclusions. In the case of the specimens of Ptilophyllum antarcticum sensu Archangelsky and Baldoni (1972) from the 

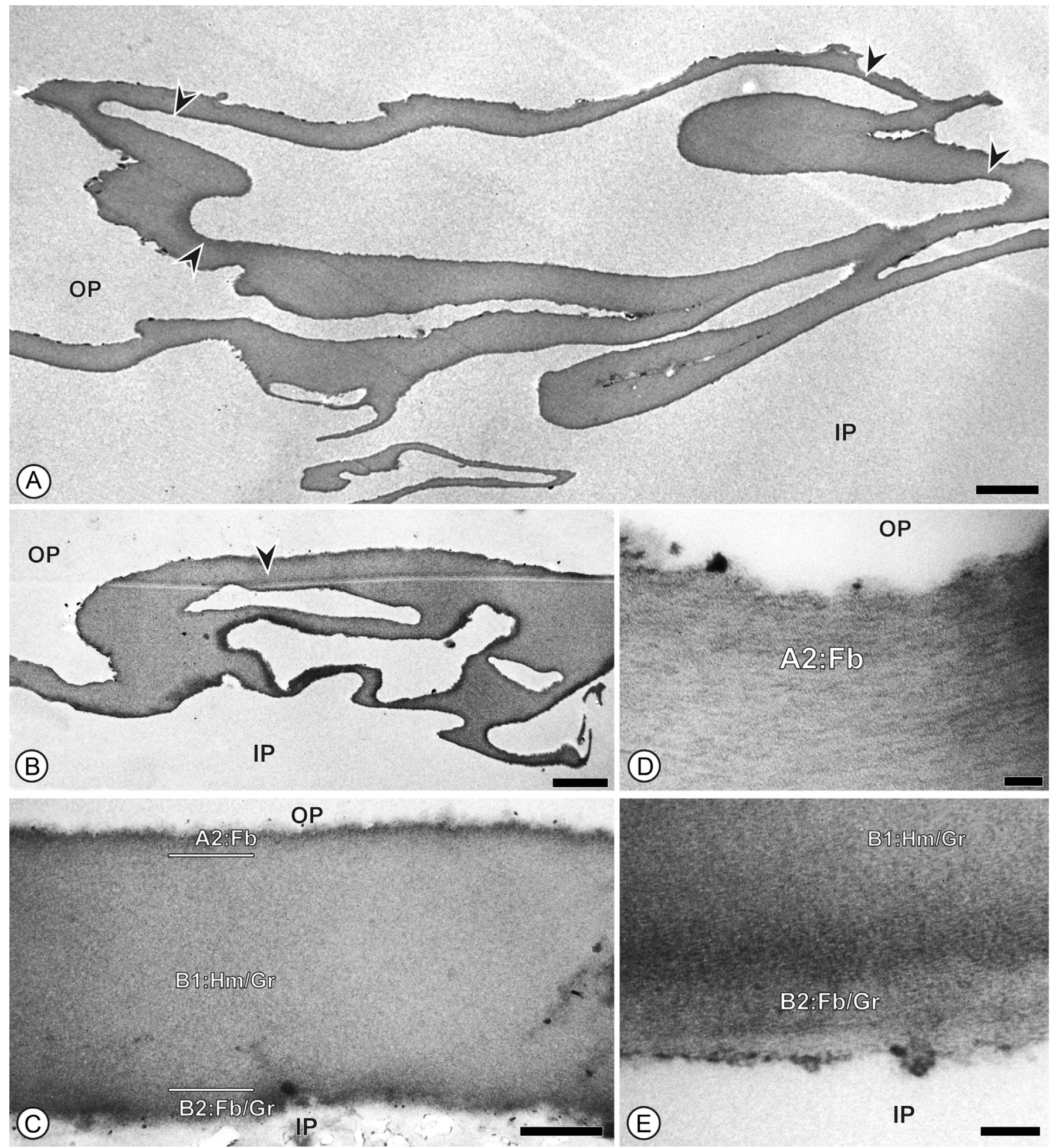

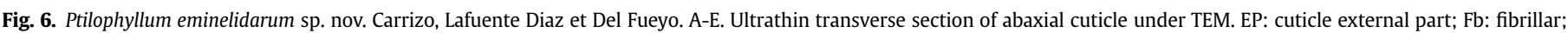

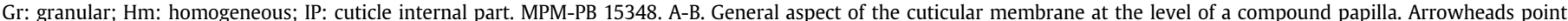


layers. Scale bar $0.5 \mu \mathrm{m}$; D-E. Detail of B1 and B2 layers. Scale bars $40 \mathrm{~nm}$.

Baqueró Group, the simple papillae are predominant and the compound papillae are mostly individual showing up to 3 irregular segments, whereas in P. antarcticum sensu Baldoni (1979) from the Springhill Formation, the compound papillae are the dominant type, being more commonly fused and with more than 6 irregular segments (Fig. 7D). Even though Baldoni (1979) had already pointed out these differences, she retained her materials in $P$. antarticum. On the contrary, we consider that the epidermal characteristics of these taxa are distinguishable enough to differentiate each into two distinct species. However, this taxonomic 

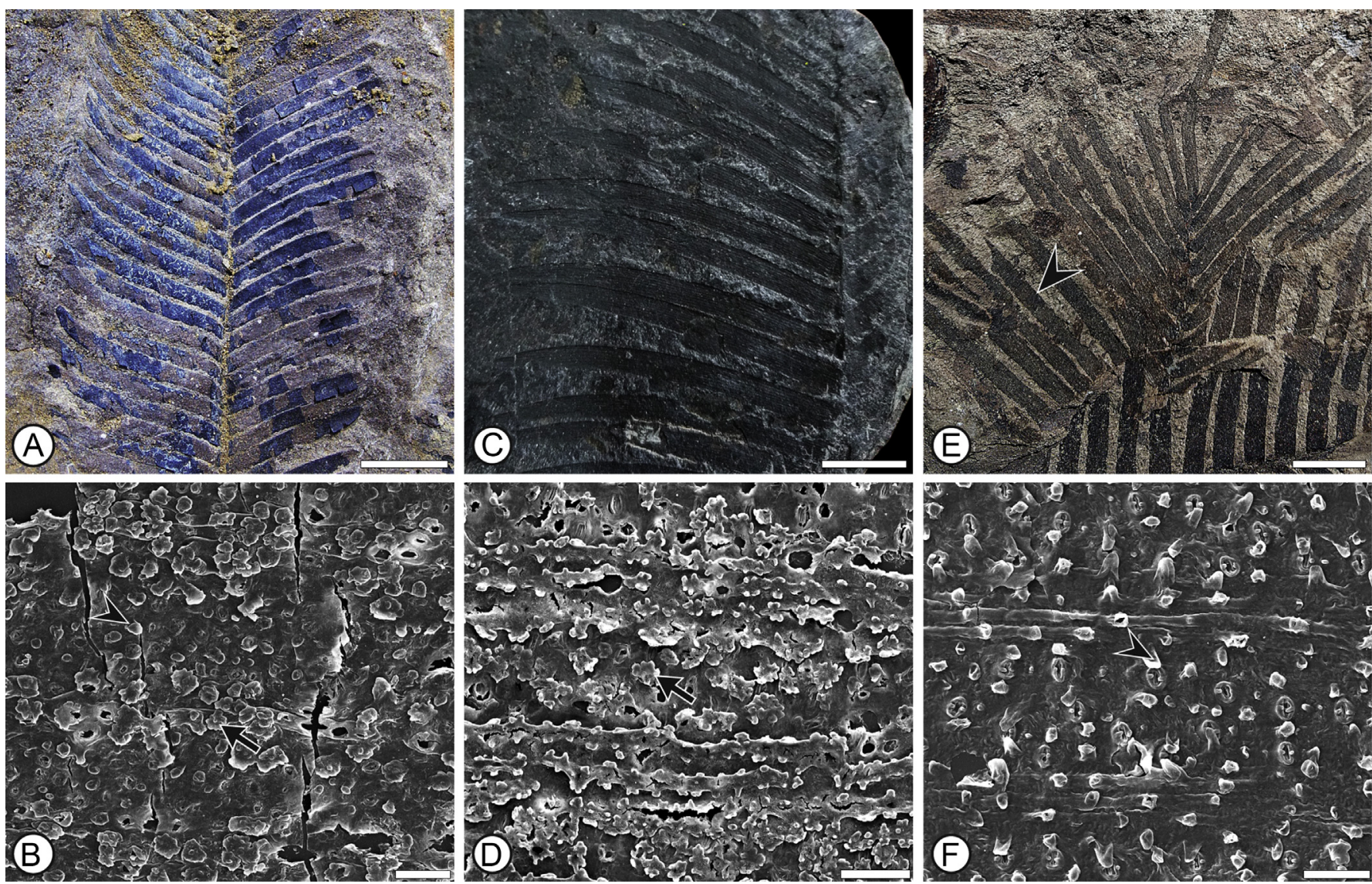



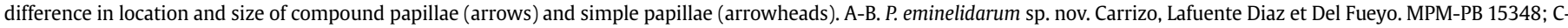
D. P. antarcticum Archangelsky et Baldoni. LP Pb 11356; E-F. P. longipinnatum Menéndez (arrowhead). LP Pb 5221 . Scale bars a. 2 cm; c,e. 1 cm; b,d,f. 100 um.

study is beyond the scope of this contribution, because a complete analysis of the cuticular analysis of specimens of $P$. antarcticum from the Baqueró Group and those from the Springhill Formation is being carried out by the authors to properly erect a new taxon for the Baldoni's (1979) materials.

Regarding $P$. longipinnatum, the re-study of the foliar cuticle from Menéndez's (1966) original material show that it is quite distinct from $P$. antarcticum (Fig. 7C-F). The former has fewer papillae, and the simple type is predominant over the compound type. Also, the subsidiary cells have a small papilla overarching the stomata. For this reason, P. longipinnatum is here used in the sense of Menéndez (1966).

\subsection{The papillae and their relevance for the distinction of the species}

Taking into consideration that the leaves of Ptilophyllum are one of the most common fossils found in the Springhill Formation, and besides the nomenclatural problems that may occur as mentioned above, the study of the cuticle features was fundamental for avoiding taxonomical conflicts. When we first compared the epidermal morphology of Ptilophyllum eminelidarum sp. nov. with those of coetanean species from Western Gondwana (Table 1, see Appendix), it was evident that there was a lack in the literature of a proper description and characterization of important characters such as the papillae. When present, the papillae's size, form and distribution are relevant characteristics for the differentiation of the species. As it is shown in Figure 7, three similar frond morphologies (Fig. 7A,C,E) present three different types and distribution of papillae (Fig. 7B,D,F), and therefore delimit three unique species: $P$. eminelidarum sp. nov., $P$. antarcticum and $P$. longipinnatum, respectively. Based on this, we propose in this work the use of two main types of papillae to distinguish between these three taxa: simple and compound (Fig. 8). The simple papilla can be small, dome-shaped, that occurs only in the center of the cell and has a width very similar to its height; or a big rounded papilla, commonly with more height than width, comprising almost all the surface of the cell. On the contrary, the compound papilla is usually more robust than the simple papilla and has numerous irregular lobulated-segments of different sizes; moreover, it is found as individual papilla or fused apically with other neighboring papilla forming a more elaborate structure (Fig. 8). In inner view, the simple papilla cell is more quadrangular than the compound papilla, whereas in the simple papilla the sinuosity of the anticlinal walls is usually more marked. In contrast, the compound papilla cell is more oval-shaped, the hole is bigger and the sinuosity of the anticlinal wall is less evident. The two simple types of papillae are found in all the epidermis of $P$. longipinnatum (Fig. 7F), or in the ordinary cells surrounding the stomata in $P$. eminelidarum sp. nov. (Figs. 4B-C; 7B). The compound papillae occur in all the epidermal cells of $P$. antarcticum (Fig. 7D) and only in the vein cells of P. eminelidarum (Figs. 4C-D; 7B).

\subsection{Comparisons}

It is noteworthy that several species descriptions lack detailed information regarding diagnostic epidermal characters. For example, some diagnoses claim the presence of unicellular hairs 


\section{Outerview}

Big

Simple
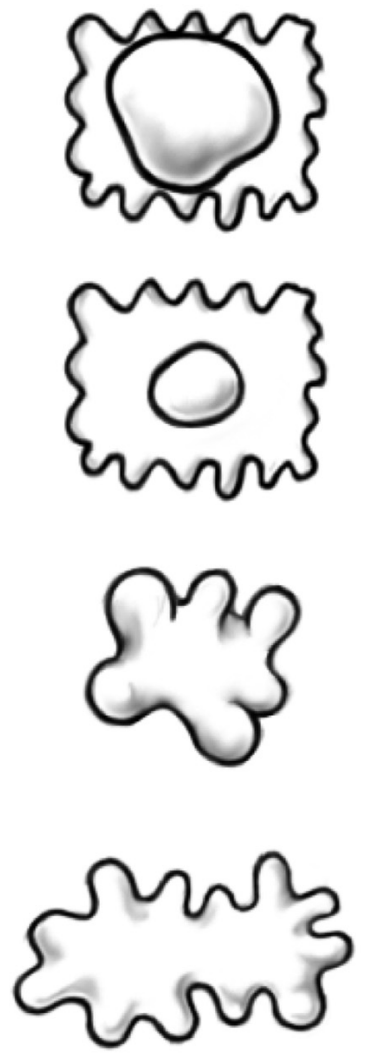

Lateral view
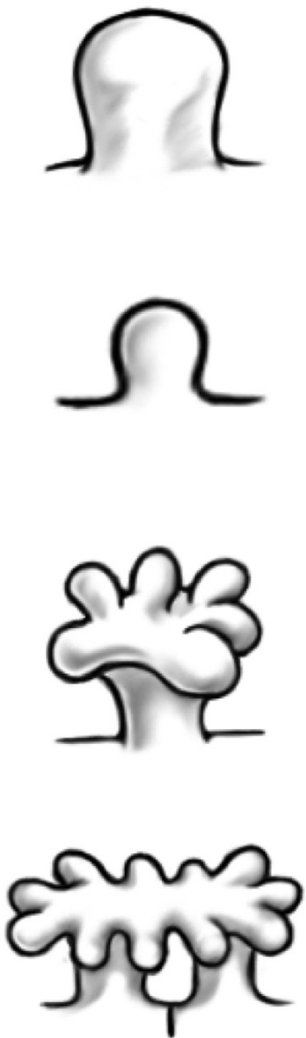

Inner view
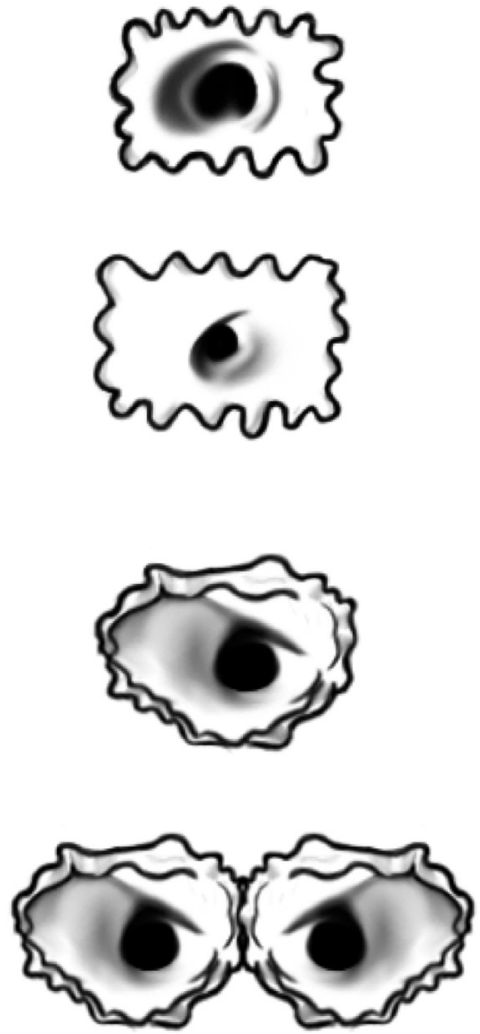

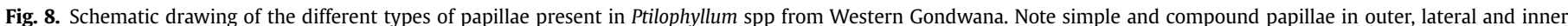
views.

(mostly mentioned as hair bases) as well as of the papillae, however they do not appear properly illustrated. Despite this, and of the problematic taxonomy of some species of Pthilophyllum, it was possible to compare and differentiate the morphology of the leaves and epidermal characteristics of $P$. eminelidarum nov. sp with that of the other coetanean species of the genus from the Western Gondwana (Table 1, see Appendix). Thus, the comparison of P. eminelidarum nov. sp will be made with those described species with preserved cuticular features.

The gross morphology of Ptilophyllum eminelidarum sp. nov. differs from that of $P$. menendezii Cantrill in that the latter has larger falcate-leaflets (32-80 $\mathrm{mm}$ long $\times 3-9 \mathrm{~mm}$ wide). Although the external morphology of the cuticle is not detailed in Cantrill (2000), the inner cuticle of $P$. menendezii shows obliquely-oriented guard cells and larger subsidiary (60 $\mu \mathrm{m}$ long $\times 35 \mu \mathrm{m}$ wide) and guard cells (50 $\mu \mathrm{m}$ long), not observed in P. eminelidarum sp. nov.

Of the three species of Ptilophyllum already known for the Springhill Formation, Ptilophyllum ghiense Baldoni, P. angustus Baldoni et Taylor and P. valvatum Villar de Seoane, none show an epidermis with the arrangement of simple papillae only among the stomata and compound papillae on the venation as does $P$. eminelidarum. In addition, $P$. ghiense differentiates from the new Patagonian taxon because it has larger, linear leaflets $(4.5 \mathrm{~cm}$ long $\mathrm{x}$ $0.6 \mathrm{~cm}$ wide), the stomatal apparatuses are commonly associated with hair bases, the subsidiary cells are larger (50 $\mu \mathrm{m}$ long), and the papillae are only simple (Baldoni, 1977).

The leaflets of $P$. angustus are smaller ( $3 \mathrm{~cm}$ long $x 0.4 \mathrm{~cm}$ wide) than those of $P$. eminelidarum sp. nov. and although the epidermis shows both simple and compound papillae, the compound papillae also occur between veins and around the stomata, partially overarching the stomatal pit. Furthermore, each stomatal apparatus is surrounded by $2-3$ trichome bases not seen in $P$. eminelidarum $\mathrm{sp}$. nov. (Baldoni and Taylor, 1983). In contrast to P. eminelidarum sp. nov. the abaxial epidermis of $P$. valvatum is densely covered by hairs and exclusively compound papillae; the subsidiary cells are papillate and overarch the pit of the stomata chamber. The cuticular membrane in $P$. valvatum is formed by three granular layers, being the outer and inner layers more electron-dense than the middle one; characters not found in P. eminelidarum sp. nov. (Villar de Seoane, 1995, 2001).

In the case of Ptilophyllum antarcticum, the specimens collected from the Springhill Formation and described by Baldoni (1979) are distinguished from those of $P$. eminelidarum sp. nov. by their epidermal characteristics. Ptilophyllum antarcticum has numerous hair bases and compound papillae located all over the epidermis and overlapping the stomatal pits. The vein concentration is higher (30-50 per $\mathrm{cm})$; the ordinary epidermal cells in the adaxial epidermis are longer (100 $\mu \mathrm{m}$ long $\times 25-30 \mu \mathrm{m}$ wide), and the crests of the sinuosity of the anticlinal walls are deeper $(10-13 \mu \mathrm{m})$. Moreover, the dorsal thickenings of the occlusive cells are poorly developed. In contrast, the leaflets of the specimens of P. antarcticum described from the Baqueró Group by Archangelsky and Baldoni (1972) are commonly linear, occasionally falcate and have a higher vein concentration $(40-50 \times \mathrm{cm})$. Furthermore, both papillae (simple and compound) are present covering the whole surface of the epidermis; the simple papillae are more abundant 
and the compound papillae have only 2-3 segments each. In addition, hair bases are found surrounding the stomata, characteristics not observed in P. eminelidarum sp. nov. (Archangelsky and Baldoni, 1972).

The leaflets of $P$. longipinnatum Menéndez are longer and thinner ( $5 \mathrm{~cm}$ long $\times 0.2 \mathrm{~cm}$ wide), commonly linear, and occasionally falcate in their distal portion. The stomatal apparatuses are arranged in at least two poorly defined rows. The papillae are more scattered and dominated by the simple type, while the slightly compound type are less common. A small papilla is always placed in each subsidiary cell partially overarching the stomatal pit, while in P. eminelidarum sp. nov. they are usually absent. Ultrastructurally, Ptilophyllum eminelidarum sp. nov. differentiates from $P$. longipinnatum due to the presence in the latter of an alveolate outer layer with elongated lacunae united by large channels perpendicular to the surface and a lamellate-reticulate inner layer (Menéndez, 1966; Villar de Seoane, 2003). Finally, Ptilophyllum hislopi (Oldham) Seward differs from P. eminelidarum sp. nov. because of the smaller size of the leaflets $(1.7 \mathrm{~cm}$ long $\times 0.3 \mathrm{~cm}$ wide), and the lack of compound papillae in the epidermis (Menéndez, 1966).

The gross morphology of the leaves described here and the presence of leaflets with a decurrent lower margin and multiple parallel veins are consistent with the diagnosis of Ptilophyllum Morris. However, the combination of both morphological and cuticular foliar characters, such as the dimension of the leaflets and the type, form, distribution, and number of lobules of the papillae, observed in the leaves of the Springhill Formation specimens are not found in any of the coetanean species of the genus described for the Cretaceous of Western Gondwana, which justify the erection of a new taxon, Ptilophyllum eminelidarum sp. nov.

\subsection{Paleoecology}

The Springhill Formation's depositional environment is considered a transgressive sequence with a transition from fluvial systems to a coastal plain with some tidal influence. It gradually passes into an estuarine setting that grades at last into an openmarine depositional system (Cortiñas and Arbe, 1981; Giacosa and Franchi, 2001; Arbe, 2002; Spalletti et al., 2009; Schwarz et al., 2011). According to geological and palynological evidence, such as the presence of a high percentage of quartz, moderate amounts of kaolinite, and almost a complete lack of feldspar; the occurrence of massive, greyish mudstones with incipient pedogenetic features, and the dominance of fern spores and some palm pollen grains, it is suggested that the Springhill Formation was probably deposited under humid climate conditions in a warm to sub tropical-wet environment (Riccardi, 1971; Baldoni and Archangelsky, 1983; Archangelsky and Archanglelsky, 2004; Schwarz et al., 2011; Martinez et al., 2016).

The presence of trichomes, sunken stomata, cuticular striations and a thick cuticle in the epidermis of plants is associated with several functions, such as water repellence/self-cleaning, defense against predation, protection from light and toxic atmospheric gases, and as a response to soil-nutrient deficiencies (Haworth and McElwain, 2008, 2009). In plants that live under stressed conditions, specifically dry environments, these characters are generally considered xeromorphics features, where the main function of these characters is to aid in the reduction of the transpiration rate by increasing the boundary layer (Johnson, 1975; Ihlenfeldt and Hartmann, 1982; Willmer and Fricker, 1996; Evert, 2006). However, in plants growing in humid regions with a high rate of precipitation, the occurrence of trichomes, sunken stomata and cuticular striations are correlated with extremely wet environments, by protecting the leaves against epiphytes, or assisting water to drain off the leaf surface (Hill, 1998a, b).

The epidermal features observed in the cuticle of Ptilophyllum eminelidarum sp. nov., such as the combination of compound and simple papillae, and the presence of sunken stomata, can be considered an adaptation to the wet, fluctuating climate produced by the gradual transition from fluvial to an estuarine and marine setting that characterizes the Springhill Formation. These features are also in concordance with the general morphology observed in the epidermis of most of the megaflora from this geological unit, as it was established by Carrizo and Del Fueyo (2015).

In addition, the fossil record of Ptilophyllum eminelidarum nov. $\mathrm{sp}$ in the Rio Correntoso locality are found in the same fossiliferous beds than Ruflorinia orlandoi Carrizo et Del Fueyo suggesting a close association between them, probably forming open communities, along with Cycadales and Ginkgoales, near the fluvial system that characterize the deposits of the Springhill Formation (Archangelsky and Archanglelsky, 2004; Carrizo et al., 2014; Carrizo and Del Fueyo, 2015).

\section{Conclusions}

A new species of the Bennettitales, Ptilophyllum eminelidarum sp. nov., is herein described on the basis of the combination of their foliar morphology and cuticular characters, which differ from those present in other species of Ptilophyllum from the Cretaceous of Gondwana.

The new taxon from the Springhill Formation at the Río Correntoso and Estancia El Salitral localities is characterized by pinnate leaves with an epidermis with papillae of two distinct morphologies uniformly distributed along the lamina of the leaflet. The papillae situated on the vein cells are exclusively compound, while those located on the ordinary cells among the stomata, between the veins, are mostly simple. This set of features are unique to this species and through this finding it complements and reinforces the previous knowledge about the megaflora of the Springhill Formation, the number of known species of Ptilophyllum is expanded up to five, and underscores the importance of the Bennettitales during the Cretaceous of Patagonia.

As the knowledge of the megaflora of the Springhill Formation grows and the diversity of Ptilophyllum leaves increase, the description and characterization of the cuticle and the papillae are essential tools for the differentiation of the species and are fundamental keys to solve the taxonomical conflict with some of the Cretaceous taxa from Western Gondwana such as P. antarcticum, P. longipinnatum and P. menendezii.

\section{Acknowledgements}

This research was partially supported by grants CONICET PIP 212/12, PICT 528/12 and PICT 2206/2015. We express our special thanks to Orlando Cárdenas for all his unconditional help and support during the field trips. We also thank the owners and employees of the Estancia Suyai (Vladimiro Macharashvili, Santiago and Miguel Crozzoli, Griselda Garrido, Raquel Cuevas), Estancia El Salitral (Elida y Sebastián García) and Estancia El Correntoso (Nélida and Emilio Cvjetanovic) who kindly gave us permission to prospect and visit the fossiliferous localities situated in their properties, and helped us in many aspects of the field logistics. We are grateful to Prof. Eduardo Morel, Curator of the Paleobotanical Collection of the Facultad de Ciencias Naturales y Museo of the University of La Plata for loaning the LPPB materials; to the Editor-in Chief (Dr. Eduardo Koutsoukos), the anonymous reviewers and the English linguist Gastón Lopez Rosales, for all their valuable comments and corrections, which have undoubtedly improved the manuscript. 


\section{References}

Arbe, H.A., 2002. Análisis estratigráfico del Cretácico de la Cuenca Austral. In: Haller, M.J. (Ed.), Geología y Recursos Naturales de Santa Cruz. Relatorio del XV Congreso Geológico Argentino. El Calafate, Buenos Aires, pp. 407-420.

Archangelsky, S., 1970. Fundamentos de Paleobotánica. La Plata, p. 347. República Argentina.

Archangelsky, S., 1976. Vegetales fósiles de la Formación Springhill, Cretácico, en el subsuelo de la Cuenca Magallánica, Chile. Ameghiniana 13, 141-158.

Archangelsky, S., Baldoni, A., 1972. Revisión de las Bennettitales de la Formación Baqueró (Cretácico inferior) provincia de Santa Cruz. I. Hojas. Revista Museo de La Plata (Nueva Serie), Paleontología 7, 195-265.

Archangelsky, S., Taylor, T.N., 1986. Ultrastructural studies of fossil plant cuticles. II. Tarphyderma gen. n., a Cretaceous conifer from Argentina. American Journal of Botany 73, 1577-1587.

Archangelsky, S., Archanglelsky, A., 2004. Palinología estadística en el Cretácico de la Cuenca Austral, Plataforma Continental Argentina. II. Seis perforaciones del área Gallegos. III. Discusión y conclusiones. Revista del Museo Argentino de Ciencias Naturales (Nueva Serie) 6, 245-255.

Archangelsky, S., Taylor, T.N., Kurmann, M.H., 1986. Ultrastructural studies of fossi plant cuticles: Ticoa harrisii from the early Cretaceous of Argentina. Botanical Journal of the Linnean Society 92, 101-116.

Baldoni, A.M., 1977. Ptilophyllum ghiense n. sp., una nueva bennettital de Paso Roballos, provincia de Santa Cruz. Ameghiniana 14, 53-58.

Baldoni, A.M., 1979. Nuevos elementos paleoflorísticos de la tafoflora de la Formación Spring Hill, limite Jurásico-Cretácico subsuelo de Argentina y Chile Austral. Ameghiniana 16, 103-119.

Baldoni, A.M., Archangelsky, S., 1983. Palinología de la Formación Springhil (Cretácico Inferior), subsuelo de Argentina y Chile Austral. Revista Espanola de Micropaleontologia 15, 47-101.

Baldoni, A.M., Taylor, T.N., 1983. Plant remains from a new Cretaceous site in Santa Cruz, Argentina. Review of Palaeobotany and Palynology 39, 301-311.

Bose, M., Kasat, M., 1970. The genus Ptilophyllum in India. Palaeobotanist 19, 117-159.

Brongniart, A.T., 1834. Nouvelles recherches sur la structure de l'épiderme des végétaux. Annales des Sciences Naturelles 65-71. Botanique 2nd. ser. 1.

Cantrill, D.J., 2000. A Cretaceous (Aptian) flora from President Head, Snow Island, Antarctica. Palaeontographica B 253, 153-191.

Carrizo, M.A., Del Fueyo, G.M., 2015. The Early Cretaceous megaflora of the Springhill Formation, Patagonia. Paleofloristic and Paleonvironmental inferences. Cretaceous Research 56, 93-109.

Carrizo, M.A., Del Fueyo, G.M., Medina, F.A., 2014. Foliar cuticle of Ruflorinia orlando nov. sp. (Pteridospermophyta) from the Lower Cretaceous of Patagonia. Geobios 47, 87-99.

Cleal, C.J., Zodrow, E.L., 1989. Epidermal structure of some medullosan Neuropteris foliage from the Middle and Upper Carboniferous of Canada and Germany. Palaeontology 32, 837-882.

Cortiñas, J.C., Arbe, H.A., 1981. Un nuevo afloramiento fosilífero de la Formación Springhill, en el Noroeste de la provincia de Santa Cruz. Revista de la Asociación Geológica Argentina 36, 212-214.

Cúneo, N.R., Escapa, I., Villar de Seoane, L.V., Artabe, A., Gnaedinger, S., 2010. Review of the cycads and bennettitaleans from the Mesozoic of Argentina. In: En, Gee, C.T. (Eds.), Plants in Mesozoic Time: Morphological Innovation, Phylogeny, Ecosystems. Indiana University Press, Bloomington, IN, pp. 197-214.

Del Fueyo, G.M., Archangelsky, S., 2005. A new araucarian pollen cone with in situ Cyclusphaera Elsik from the Aptian of Patagonia, Argentina. Cretaceous Research 26, 757-768.

Evert, R.F., 2006. Esau's Plant Anatomy. Wiley \& Sons, Inc., New Jersey, p. 601.

Florin, R., 1958. On Jurassic taxads and conifers from north-western Europe and eastern Greenland. Acta Horti Bergiani 17, 259-402.

Gee, C.T., 1989. Revision of the Late Jurassic/Early Cretaceous flora from Hope Bay, Antarctica. Palaeontographica B 213, 149-214.

Giacosa, R., Franchi, M., 2001. Hojas Geológicas 4772-III y 4772-IV Lago Belgrano y Lago Posadas, Provincia de Santa Cruz. Servicio Geológico Minero Argentino. Instituto de Geología y Recursos Minerales. Boletín N²56, Buenos Aires, p. 68.

Guignard, G., Del Fueyo, G.M., Villar de Seoane, L., Carrizo, M.A., Lafuente Diaz, M.A 2016. Insights into the leaf cuticle fine structure of Ginkgoites skottsbergii Lund. from the Albian of Patagonia and its relationship within Ginkgoaceae. Review of Palaeobotany and Palynology 232, 22-39.

Halle, T.G., 1913. The Mesozoic flora of Graham Land. Der Schwedischen SudpolarExpedition 3, 1-123.

Harris, T.M., 1964. The Yorkshire Jurassic Flora II. Caytoniales, Cycadales \& Pteridosperms. British Museum (Natural History), London, p. 191.

Harris, T.M., 1969. The Yorkshire Jurassic Flora III. Bennettitales. British Museum (Natural History), London, p. 186.

Haworth, M., McElwain, J., 2008. Hot, dry, wet, cold or toxic? Revisiting the ecological significance of leaf and cuticular micromorphology. Palaeogeography, Palaeoclimatology, Palaeoecology 262, 79-90.

Haworth, M., McElwain, J.C., 2009. Reply to the comment on "Hot, dry, wet, cold or toxic? revisiting the ecological significance of leaf cuticular micromorphology by M. Haworth and J.C. McElwain [Palaeogeography, Palaeoclimatology, Palaeoecology 262 (2008) 79-90]. Palaeogeography, Palaeoclimatology, Palaeoecology 273, 209-211.

Hill, R.S., 1998a. Fossil evidence for the onset of xeromorphy and scleromorphy in Australian Proteaceae. Australian Systematic Botany 11, 391-400.

Hill, R.S., 1998b. Poor soils and a dry climate: The evolution of the Australian scleromorphic and xeromorphic vegetation. Australian Biologist 11, 26-29.

Ihlenfeldt, H.D., Hartmann, H.E.K., 1982. Leaf surfaces in Mesembryanthemaceae. In: Cutler, D.F., Alvin, K.L., Price, C.E. (Eds.), The Plant Cuticle. London, pp. 397-423.

Johnson, H.B., 1975. Plant pubescence: an ecological perspective. The Botanical Review 41, 233-258.

Kerp, H., 1990. The study of fossil Gymnosperms by means of cuticular analysis. Palaios 5, 548-569.

Kerp, H., Barthel, M., 1993. Problems of cuticular analysis of pteridosperms. Review of Palaeobotany and Palynology 78, 1-18.

Martínez, L.C.A., Archangelsky, S., Prámparo, M.B., Archangelsky, A., 2016. Early Cretaceous palm pollen tetrads from Patagonia, Argentina. Cretaceous Research 59, 129-139.

Menéndez, C.A., 1966. Fossil Bennettitales from the Ticó flora, Santa Cruz province, Argentina. Bulletin of the British Museum (Natural History) Geology 12, $3-42$.

Menéndez, C.A., 1973. Acerca de la validez de Ptilophyllum longipinnatum Menéndez 1966. Ameghiniana 10, 196-197.

Mösle, B., Finch, P., Collinson, M.E., Scott, A.C., 1997. Comparison of modern and fossil plant cuticles by selective chemical extraction monitored by flash pyrolysis-gas chromatography-mass spectrometry and electron microscopy. Journal of Analytical and Applied Pyrolysis 40 - 41, 585-597.

Nathorst, A.G., 1908. Paläobotanische Mitteilungen. 4. Über die Untersuchung kutinisierter fossiler Pflanzenteile. Kungl - Svenska Vetenskapsakademiens Handlingar 43, 3-26.

Oldham, T.C.B., 1976. Flora of the Wealden plant debris beds of England. Palaeontology 19, 437-502.

Ottone, E.G., Aguirre-Urreta, M.B., 2000. Palinomorfos cretácicos de la Formación Springhill en Estancia El Salitral, Patagonia Austral, Argentina. Ameghiniana 37, 375-378.

Pott, C., Krings, M., Kerp, H., 2007. A surface microrelief on the leaves of Glossophyllum florinii (?Ginkgoales) from the Upper Triassic of Lunz, Austria. Botanical Journal of the Linnean Society 153, 87-97.

Riccardi, A.C., 1971. Estratigrafía en el oriente de la Bahía de la Lancha, Lago San Martín, Santa Cruz, Argentina. Revista del Museo de La Plata - Seccion Geologia 7, 245-318.

Riccardi, A.C., 1976. Paleontología y edad de la Formación Springhill. In: Primer Congreso Geológico Chileno, 1. Santiago, Chile, pp. C41-C56.

Schwarz, E., Veiga, G.D., Spalletti, L.A., Massaferro, J.L., 2011. The transgressive infill of an inherited-vallet system: The Springhill Formation (lower Cretaceous) in southern Austral Basin, Argentina. Marine and Petroleum Geology 28, $1218-1241$.

Sincock, C.A., Watson, J., 1988. Terminology used in the description of Bennettitalean cuticle characters. Botanical Journal of the Linnean Society 97, 179-187.

Spalletti, L.A., Schwarz, E., Veiga, G.D., Matheos, S.D., Haring, C., Covellone, G., 2009. Análisis paleoambiental y estratigráfico secuencial de alta resolución de la Formación Springhill al este de Tierra del Fuego (Cuenca Austral, Argentina). In: XII Congreso Geológico Chileno, Santiago. Actas, pp. 1-4.

Sukh-Dev, Zeba-Bano, 1977. Three species of Ptilophyllum from Bansa, Madhya Pradesh. Palaeobotanist 24, 161-169.

Thomas, H.H., 1915. On Williamsoniella, a new type of Bennettitalean flower. Philosophical transactions of the Royal Society B 207, 113-148.

Thomas, C.R., 1949. Manantiales Field, Magallanes Province, Chile. American Association of Petroleum Geologists 33, 1579-1589.

Taylor, T.N., Taylor, E.L., Krings, M., 2009. Paleobotany: The Biology and Evolution of Fossil Plants, second ed. Academic Press, Burlington, MA, p. 1230.

Villar de Seoane, L., 1995. Estudio cuticular de nuevas Bennettitales eocretácicas de Santa Cruz, Argentina. In: VI Congreso Argentino de Paleontología y Bioestratigrafía, Actas, pp. 247-254.

Villar de Seoane, L., 2001. Cuticular study of Bennettitales from the Springhill Formation, Lower Cretaceous of Patagonia, Argentina. Cretaceous Research 22, $461-479$.

Villar de Seoane, L, 2003. Cuticle ultrastructure of the Bennettitales from the Anfiteatro de Ticó Formation (early Aptian), Santa Cruz Province, Argentina. Review of Palaeobotany and Palynology 127, 59-76.

Watson, J., Sincock, C.A., 1992. Bennettitales of the English Wealden. Monograph of the Palaeontographical Society, London, p. 228.

Willmer, C., Fricker, M., 1996. Stomata. Chapman and Hall, London, p. 375.

\section{Appendix A. Supplementary data}

Supplementary data to this article can be found online at https://doi.org/10. 1016/j.cretres.2019.01.013. 